\title{
PERLINDUNGAN DAN PENGELOLAAN LINGKUNGAN HIDUP TERKAIT PEMANFAATAN RUANG UNTUK TAMAN NASIONAL
}

\author{
Oleh \\ Meta Indah Budhianti *)
}

\section{Abstrak}

Penataan ruang dalam perlindungan dan pengelolaan lingkungan hidup memiliki peranan yang sangat penting. Penataan Ruang pada dasarnya terdiri dari aspek perencanaan tata ruang, pemanfaatan ruang dan pengendalian pemanfaatan ruang. Permasalahan pokoknya: Bagaimana kesesuaian pengaturan perlindungan dan pengelolaan lingkungan hidup terkait pemanfaatan ruang untuk Taman Nasional dengan Undang-Undang Nomor 26 Tahun 2007 tentang Penataan Ruang (UndangUndang Penataan Ruang); kendala apa yang ditemukan Pemerintah Daerah (Pemda) dalam pengelolaan Taman Nasional dan bagaimana pengaturan yang ideal mengenai pengelolaan Taman Nasional agar Pemda dapat berperan sesuai dengan amanat Undang-Undang Penataan Ruang. Metode penelitian yang digunakan adalah tipe penelitian normatif yang didukung oleh data empiris. Pengolahan data dilakukan secara kualitatif. Hasilnya adalah: Dalam praktek, kewenangan Pemda hanya bersifat koordinasi dengan Unit Pelaksana Tugas (UPT) Balai Taman Nasional, yaitu memelihara kelestarian hutan. Sedangkan dalam Undang-Undang Penataan Ruang, kewenangan kawasan strategis, dalam hal ini taman nasional, dilaksanakan Pemerintah Pusat dan Pemerintah Daerah. Pada dasarnya pengelolaan kawasan konservasi Taman Nasional, dalam penelitian ini di Bali Barat dan Bukit Baka Bukit Raya, menghadapi berbagai persoalan yang kompleks dan beragam. Persoalan dapat dikelompokkan ke dalam persoalan internal dan eksternal. Untuk meningkatkan manfaat wilayah atau kawasan yang maksimal diperlukan perhatian yang teliti terhadap perlindungan lingkungan, efisiensi, sinergi dan keserasian pada potensi ekonomi di lingkungan tersebut. Ini dapat diartikan bahwa pentingnya keterpaduan dalam perencanaan pembangunan adalah untuk mencapai peningkatan kesejahteraan yang maksimal.

\section{Kata Kunci : Pemanfaatan Ruang, Penataan Ruang}

\section{A.PENDAHULUAN}

Kegiatan pembangunan juga mengandung risiko terjadinya pencemaran dan kerusakan lingkungan. Kondisi ini dapat mengakibatkan daya dukung, daya tampung, dan produktivitas lingkungan hidup menurun yang pada akhirnya menjadi beban sosial. Oleh karena itu, lingkungan hidup Indonesia harus dilindungi dan dikelola dengan

*) Penulis adalah Dosen Fakultas Hukum Universitas Trisakti Jakarta baik berdasarkan asas tanggung jawab negara, asas keberlanjutan, dan asas keadilan. Selain itu, pengelolaan lingkungan hidup harus dapat memberikan kemanfaatan ekonomi, sosial, dan budaya yang dilakukan berdasarkan prinsip kehati-hatian, demokrasi lingkungan, desentralisasi, serta pengakuan dan penghargaan terhadap kearifan lokal dan kearifan lingkungan perlindungan dan pengelolaan lingkungan 
hidup menuntut dikembangkannya suatu sistem yang terpadu berupa suatu kebijakan nasional perlindungan dan pengelolaan lingkungan hidup yang harus dilaksanakan secara taat asas dan konsekuen dari pusat sampai ke daerah. ${ }^{1}$

Dalam rangka pelaksanaan pembangunan nasional digariskan kebijaksanaan nasional dibidang pertanahan, bahwa Hukum Tanah Nasional harus pula merupakan pelaksanaan Pasal 33 ayat (3) Undang-Undang Dasar 1945 yang merupakan dasar hukum yang utama dari Hukum Tanah. Adapun bunyi Pasal 33 ayat (3) UndangUndang Dasar 1945 sebagai berikut: "Bumi dan air dan kekayaan alam yang terkandung didalamnya dikuasai oleh negara dan dipergunakan untuk sebesar-besarnya kemakmuran rakyat" Sebagai tindak lanjut dari Politik Pertanahan Nasional ini, pada tanggal 24 September 1960 diterbitkan UndangUndang No. 5 Tahun 1960 (Lembaran Negara Republik Indonesia Tahun 1960 No. 104) tentang Peraturan Dasar Pokok-Pokok Agraria. Undang-Undang ini lebih dikenal dengan sebutan UUPA. Dengan diterbitkannya UUPA berikut peraturan pelaksanaannya, maka penyediaan dan pengembangan tanah Indonesia, harus mengindahkan politik pertanahan nasional dan aturan-aturan yang berlaku. ${ }^{2}$

Semua kegiatan di atas tanah wilayah Republik Indonesia kewenangan mutlak ada pada Negara yang dilimpahkan kepada Pemerintah Daerah (Pemda) Kabupaten atau Kota untuk mengatur Penatagunaan Tanah, seperti

${ }^{1}$ Ibid., Penjelasan umum butir 2.

2 Boedi Harsono. Hukum Agraria Indonesia. Sejarah Pembentukan Undang-Undang Pokok Agraria, Isi dan Pelaksanaannya (Jakarta: Universitas Trisakti, 2013), hlm. 1 . yang tercantum dalam Pasal 2 ayat (1), (2), (3), Pasal 14 dan Pasal 15 UU No. 5 Tahun 1960 tentang Peraturan Dasar Pokok-Pokok Agraria, yang bersumber pada Hak Menguasai dari Negara yang digunakan untuk sebesar-besarnya kemakmuran rakyat yang sesuai dengan politik pertanahan nasional yang tercantum dalam Pasal 33 ayat (3) UUD 1945.

Penataan ruang dalam perlindungan dan pengelolaan lingkungan hidup memiliki peranan yang sangat penting. Hal ini bisa kita lihat didalam UndangUndang Nomor 26 Tahun 2007 tentang Penataan Ruang dan dalam UndangUndang Nomor 32 Tahun 2009 tentang Perlindungan dan Pengelolaan Lingkungan Hidup ada benang merah yang menghubungkan dua peraturan tersebut dalam konteks usaha perlindungan lingkungan tentunya.

Penataan ruang dipandang sebagai upaya untuk memanfaatkan sumber daya alam sebesar-besarnya bagi kesejahteraan rakyat. Namun demikian, penataan ruang juga harus dapat menjamin kelestarian sumber daya alam agar dapat berfungsi secara terusmenerus. Karena sifat penataan ruang yang irrevesible maka perencanaan penataan ruang harus mempertimbangkan kebutuhan, kemampuan dan kapasitas dalam melaksanakan dan mengendalikan pelaksanaan tata ruang yang disusun.

Sumber daya alam hayati adalah unsur-unsur hayati di alam yang terdiri dari sumber daya alam nabati (tumbuhan) dan sumber daya alam hewani (satwa) yang bersama dengan unsur non hayati di sekitarnya secara keseluruhan membentuk ekosistem, ${ }^{3}$

3 Indonesia, Undang-Undang Nomor 5 Tahun 1990 tentang Konservasi Sumber Daya Alam Hayati, Pasal 1 angka 1, Lembaran Negara Tahun 1990 No. 49. 
sedangkan ekosistem sumber daya alam hayati adalah sistem hubungan timbal balik antara unsur dalam alam, baik hayati maupun non hayati yang saling tergantung dan pengaruh mempengaruhi. Konservasi sumber daya alam hayati adalah pengelolaan sumber daya alam hayati yang pemanfaatannya dilakukan secara bijaksana untuk menjamin kesinambungan persediaannya dengan tetap memelihara dan meningkatkan kualitas keanekaragaman dan nilainya. 4 Konservasi sumber daya alam hayati dan ekosistemnya dilakukan melalui kegiatan: 5

1. Perlindungan sistem penyangga kehidupan;

2. Pengawetan keanekaragaman jenis tumbuhan dan satwa beserta ekosistemnya

3. Pemanfaatan secara lestari sumber daya alam hayati dan ekosistemnya. Kawasan konservasi sendiri merupakan kawasan hutan yang ditetapkan untuk perlindungan ekosistem dan spesies (flora, fauna, dan biodiversity). Menurut fungsinya, kawasan konservasi dibedakan menjadi dua yakni kawasan perlindungan alam dan suaka alam. Untuk kawasan perlindungan alam meliputi Taman Nasional, Taman Hutan Raya, serta Taman Wisata. Sedangkan yang termasuk dalam suaka alam adalah suaka margasatwa dan cagar alam. Namun saat ini, sebagian besar kawasan konservasi mengalami degradasi baik fungsi maupun kuantitasnya. Selain karena faktor alam (misalnya erupsi gunung berapi, gempa bumi ataupun tsunami) juga disebabkan oleh perubahan fungsi dan ulah manusia.

Menurut Undang-Undang Nomor 5 Tahun 1990 tentang Konservasi Sumber Daya Alam Hayati dan Ekosistem-

4 Ibid., Pasal 1 angka 2.

5 Ibid., Pasal 5. nya, Taman Nasional didefinisikan sebagai kawasan pelestarian alam yang mempunyai ekosistem asli, dikelola dengan sistem zonasi yang dimanfaatkan untuk tujuan penelitian, ilmu pengetahuan, pendidikan, menunjang budidaya, pariwisata dan rekreasi alam. ${ }^{6}$

Mengingat sedemikian penting-nya arti kawasan tersebut bagi kelangsungan hidup setiap makhluk, maka pemerintah mengeluarkan berbagai kebijakan pengelolaan Taman Nasional yang dilengkapi dengan perangkat perundang-undangan sebagai pijakan dalam menjalankan tugas pengelolaan Taman Nasonal.

Dari uraian di atas yang menjadi permasalahannya adalah:

1. Bagaimana kesesuaian pengaturan perlindungan dan pengelolaan lingkungan hidup terkait pemanfaatan ruang untuk Taman Nasional dengan Undang-Undang Nomor 26 Tahun 2007 tentang Penataan Ruang?

2. Kendala apa yang ditemukan Pemerintah Daerah dalam pengelolaan Taman Nasional?

3. Bagaimana pengaturan yang ideal mengenai pengelolaan Taman Nasional agar Pemerintah Daerah dapat berperan sesuai dengan amanat Undang-Undang Nomor 26 Tahun 2007 tentang Penataan Ruang?

\section{B. PEMBAHASAN}

1. Pengaturan Perlindungan Dan Pengelolaan Lingkungan Hidup Terkait Pemanfaatan Ruang Untuk Taman Nasional

Dalam rangka klasifikasi penataan ruang ditegaskan dalam Pasal 4 UUPR bahwa: Penataan ruang diklasifikasi-

6 Ibid., Pasal 1 angka 14. 
kan berdasarkan sistem, fungsi utama kawasan, wilayah administratif, kegiatan kawasan, dan nilai strategis kawasan.

Selanjutnya dalam Pasal 5 UUPR ditegaskan bahwa:

1. Penataan ruang berdasarkan sistem terdiri atas sistem wilayah dan sistem internal perkotaan.

2. Penataan ruang berdasarkan fungsi utama kawasan terdiri atas kawasan lindung dan kawasan budidaya.

3. Penataan ruang berdasarkan wilayah administratif terdiri atas penataan ruang wilayah nasional, penataan ruang wilayah provinsi, dan penataan ruang wilayah kabupaten/kota.

4. Penataan ruang berdasarkan kegiatan kawasan terdiri atas penataan ruang kawasan perkotaan dan penataan ruang kawasan perdesaan.

5. Penataan ruang berdasarkan nilai strategis kawasan terdiri atas penataan ruang kawasan strategis nasional, penataan ruang kawasan strategis provinsi, dan penataan ruang kawasan strategis kabupaten/kota.

Penataan ruang berdasarkan fungsi utama kawasan merupakan komponen dalam penataan ruang baik yang dilakukan berdasarkan wilayah administratif, kegiatan kawasan, maupun nilai strategis kawasan. Yang termasuk dalam kawasan lindung adalah:

a. Kawasan yang memberikan perlindungan kawasan bawahannya, antara lain, kawasan hutan lindung, kawasan bergambut, dan kawasan resapan air;

b. Kawasan perlindungan setempat, antara lain, sempadan pantai, sempadan sungai, kawasan sekitar danau/waduk, dan kawasan sekitar mata air; c. Kawasan suaka alam dan cagar budaya, antara lain, kawasan suaka alam, kawasan suaka alam laut dan perairan lainnya, kawasan pantai berhutan bakau, taman nasional, taman hutan raya, taman wisata alam, cagar alam, suaka margasatwa, serta kawasan cagar budaya dan ilmu pengetahuan;

d. Kawasan rawan bencana alam, antara lain, kawasan rawan letusan gunung berapi, kawasan rawan gempa bumi, kawasan rawan tanah longsor, kawasan rawan gelombang pasang, dan kawasan rawan banjir; dan

e. Kawasan lindung lainnya, misalnya taman buru, cagar biosfer, kawasan perlindungan plasma nutfah, kawasan pengungsian satwa, dan terumbu karang.

Kawasan budidaya adalah kawasan peruntukan hutan produksi, kawasan peruntukan hutan rakyat, kawasan peruntukan pertanian, kawasan peruntukan perikanan, kawasan peruntukan pertambangan, kawasan peruntukan permukiman, kawasan peruntukan industri, kawasan peruntukan pariwisata, kawasan tempat beribadah, kawasan pendidikan, dan kawasan pertahanan keamanan.

Kawasan strategis dari sudut kepentingan sosial dan budaya, antara lain, adalah kawasan adat tertentu, kawasan konservasi warisan budaya, termasuk warisan budaya yang diakui sebagai warisan dunia, seperti Kompleks Candi Borobudur dan Kompleks Candi Prambanan.

Kawasan strategis dari sudut kepentingan fungsi dan daya dukung lingkungan hidup, antara lain, adalah kawasan pelindungan dan pelestarian lingkungan hidup, termasuk kawasan yang diakui sebagai warisan dunia seperti Taman Nasional Lorentz, Taman Nasional Ujung Kulon, dan Taman Na- 
sional Komodo. Nilai strategis kawasan tingkat nasional, provinsi, dan kabupaten/kota diukur berdasarkan aspek eksternalitas, akuntabilitas, dan efisiensi penanganan kawasan sebagaimana dimaksud dalam Undang-Undang Nomor 23 Tahun 2014 tentang Pemerintahan Daerah.

Menurut ketentuan Pasal 10 UUPR:

(1) Wewenang Pemerintah Daerah Provinsi dalam penyelenggaraan penataan ruang meliputi:

a. Pengaturan, pembinaan, dan pengawasan terhadap pelaksanaan penataan ruang wilayah provinsi, dan kabupaten/kota, serta terhadap pelaksanaan penataan ruang kawasan strategis provinsi dan kabupaten/kota.

b. Pelaksanaan penataan ruang wilayah provinsi;

c. Pelaksanaan penataan ruang kawasan strategis provinsi; dan

d. Kerjasama penataan ruang antarprovinsi dan pemfasilitasan kerjasama penataan ruang antarkabupaten/kota.

(2) Wewenang Pemerintah Daerah Provinsi dalam pelaksanaan penataan ruang wilayah provinsi sebagaimana dimaksud pada ayat

(1) huruf b meliputi:

a. Perencanaan tata ruang wilayah provinsi;

b. Pemanfaatan ruang wilayah provinsi; dan

c. Pengendalian pemanfaatan ruang wilayah provinsi.

(3) Dalam penataan ruang kawasan strategis provinsi sebagaimana dimaksud pada ayat (1) huruf c, Pemerintah Daerah Provinsi melaksanakan:

a. Penetapan kawasan strategis provinsi;

b. Perencanaan tata ruang kawasan strategis provinsi; c. Pemanfaatan ruang kawasan strategis provinsi; dan

d. Pengendalian pemanfaatan ruang kawasan strategis provinsi.

(4) Pelaksanaan pemanfaatan ruang dan pengendalian pemanfaatan ruang kawasan strategis provinsi sebagaimana dimaksud pada ayat (3) huruf c dan huruf d dapat dilaksanakan Pemerintah Daerah Kabupaten/Kota melalui tugas pembantuan.

(5) Dalam rangka penyelenggaraan penataan ruang wilayah provinsi, pemerintah daerah provinsi dapat menyusun petunjuk pelaksanaan bidang penataan ruang pada tingkat provinsi dan kabupaten/kota.

(6) Dalam pelaksanaan wewenang sebagaimana dimaksud pada ayat (1), ayat (2), ayat (3), ayat (4), dan ayat (5), Pemerintah Daerah Provinsi:

a. Menyebarluaskan informasi yang berkaitan dengan:

1) Rencana umum dan rencana rinci tata ruang dalam rangka pelaksanaan penataan ruang wilayah provinsi;

2) Arahan peraturan zonasi untuk sistem provinsi yang disusun dalam rangka pengendalian pemanfaatan ruang wilayah provinsi; dan

3) Petunjuk pelaksanaan bidang penataan ruang;

b. Melaksanakan standar pelayanan minimal bidang penataan ruang.

(7) Dalam hal Pemerintah Daerah Provinsi tidak dapat memenuhi standar pelayanan minimal bidang penataan ruang, Pemerintah mengambil langkah penyelesaian sesuai dengan ketentuan peraturan perundang-undangan.

Kewenangan Pemerintah Daerah Provinsi dalam pemanfaatan ruang dan 
pengendalian pemanfaatan ruang kawasan strategis provinsi mencakup aspek yang terkait dengan nilai strategis yang menjadi dasar penetapan kawasan strategis. Pemerintah Daerah Kabupaten/Kota tetap memiliki kewenangan dalam penyelenggaraan aspek yang tidak terkait dengan nilai strategis yang menjadi dasar penetapan kawasan strategis.

Yang dimaksud dengan "dapat menyusun petunjuk pelaksanaan" adalah bahwa penyusunan petunjuk pelaksanaan oleh Pemerintah Daerah Provinsi disesuaikan kebutuhan dengan memperhatikan karakteristik daerah. Petunjuk pelaksanaan dimaksud merupakan penjabaran dari pedoman bidang penataan ruang yang ditetapkan oleh Pemerintah.

Perlu ditegaskan bahwa: Pemberian wewenang kepada Pemerintah Daerah Provinsi dalam memfasilitasi kerjasama penataan ruang antar kabupaten/kota dimaksudkan agar kerjasama penataan ruang memberikan manfaat yang optimal bagi kabupaten/kota yang bekerja sama.

Dalam Pasal 11 UUPR ditegaskan:

(1) Wewenang Pemerintah Daerah Kabupaten/Kota dalam penyelenggaraan penataan ruang meliputi:

a. Pengaturan, pembinaan, dan pengawasan terhadap pelaksanaan penataan ruang wilayah kabupaten/kota dan kawasan strategis kabupaten/kota;

b. Pelaksanaan penataan ruang wilayah kabupaten/kota;

c. Pelaksanaan penataan ruang kawasan strategis kabupaten/kota; dan

d. Kerjasama penataan ruang antarkabupaten/kota.

(2) Wewenang Pemerintah Daerah Kabupaten/Kota dalam pelaksanaan penataan ruang wilayah kab- upaten/kota sebagaimana dimaksud pada ayat (1) huruf b meliputi:

a. Perencanaan tata ruang wilayah kabupaten/kota;

b. Pemanfaatan ruang wilayah kabupaten/kota; dan

c. Pengendalian pemanfaatan ruang wilayah kabupaten/kota.

(3) Dalam pelaksanaan penataan ruang kawasan strategis kabupaten/kota sebagaimana dimaksud pada ayat (1) huruf c, Pemerintah Daerah Kabupaten/Kota melaksanakan:

a. Penetapan kawasan strategis kabupaten/kota;

b. Perencanaan tata ruang kawasan strategis kabupaten/kota;

c. Pemanfaatan ruang kawasan strategis kabupaten/kota; dan

d. Pengendalian pemanfaatan ruang kawasan strategis kabupaten/kota.

(4) Dalam melaksanakan kewenangan sebagaimana dimaksud pada ayat (1) dan ayat (2), Pemerintah Daerah Kabupaten/Kota mengacu pada pedoman bidang penataan ruang dan petunjuk pelaksanaannya.

(5) Dalam melaksanakan wewenang sebagaimana dimaksud pada ayat (1), ayat (2), ayat (3), dan ayat (4), Pemerintah Daerah Kabupaten/ Kota:

a. Menyebarluaskan informasi yang berkaitan dengan rencana umum dan rencana rinci tata ruang dalam rangka pelaksanaan penataan ruang wilayah kabupaten/kota; dan

b. Melaksanakan standar pelayanan minimal bidang penataan ruang.

(6) Dalam hal Pemerintah Daerah Kabupaten/Kota tidak dapat memenuhi standar pelayanan minimal bidang penataan ruang, Pemerintah Daerah Provinsi dapat meng- 
ambil langkah penyelesaian sesuai dengan ketentuan peraturan perundang-undangan.

Ketentuan mengenai Pengendalian Pemanfaatan Ruang diatur dalam Pasal 35: Pengendalian pemanfaatan ruang dilakukan melalui penetapan peraturan zonasi, perizinan, pemberian insentif dan disinsentif, serta pengenaan sanksi. Adapun Pengendalian pemanfaatan ruang dimaksudkan agar pemanfaatan ruang dilakukan sesuai dengan rencana tata ruang.

Peraturan tentang Zonasi ditegaskan dalam Pasal 36 sebagai berikut:

(1) Peraturan zonasi sebagaimana dimaksud dalam Pasal 35 disusun sebagai pedoman pengendalian pemanfaatan ruang.

(2) Peraturan zonasi disusun berdasarkan rencana rinci tata ruang untuk setiap zona pemanfaatan ruang.

(3) Peraturan zonasi ditetapkan dengan:

a. Peraturan pemerintah untuk arahan peraturan zonasi sistem nasional;

b. Peraturan daerah provinsi untuk arahan peraturan zonasi sistem provinsi; dan

c. Peraturan daerah kabupaten/ kota untuk peraturan zonasi.

Penegasan tentang Peraturan Zonasi merupakan ketentuan yang mengatur pemanfaatan ruang dan unsur-unsur pengendalian yang disusun untuk setiap zona peruntukan sesuai dengan rencana rinci tata ruang.

Peraturan zonasi berisi ketentuan yang harus, boleh, dan tidak boleh dilaksanakan pada zona pemanfaatan ruang yang dapat terdiri atas ketentuan tentang amplop ruang (koefisien dasar ruang hijau, koefisien dasar bangunan, koefisien lantai bangunan, dan garis sempadan bangunan), penyediaan sarana dan prasarana, serta ketentuan lain yang dibutuhkan untuk mewujudkan ruang yang aman, nyaman, produktif, dan berkelanjutan.

Selain pengaturan tersebut diatur didalam Undang-Undang Nomor 26 Tahun 2007 tentang Penataan Ruang juga diatur didalam Undang-Undang No. 32 Tahun 2009 tentang Perlindungan dan Pengelolaan Lingkungan Hidup, dimana kaitannya dengan perlindungan dan pengelolaan lingkungan hidup terkait pemanfaatan ruang untuk Taman Nasional itu adalah mengenai pengendalian dimana diatur di dalam Pasal 13 Undang-Undang Nomor 32 Tahun 2009 antara lain:

1. Pengendalian pencemaran dan/ atau kerusakan lingkungan hidup dilaksanakan dalam rangka pelestarian fungsi lingkungan

2. Pengendalian pencemaran dan/ atau kerusakan lingkungan hidup sebagaimana dimaksud pada ayat (1) meliputi:

a. Pencegahan

b. Penanggulangan, dan

c. Pemulihan

3. Pengendalian pencemaran dan/ atau kerusakan lingkungan hidup sebagaimana dimaksud pada ayat (1) dilaksanakan oleh Pemerintah, Pemerintah Daerah, dan penanggung jawab usaha dan/atau kegiatan sesuai dengan kewenangan, peran dan tanggungjawab masingmasing.

Dalam hal ini pengendalian pencemaran dan/atau kerusakan lingkungan hidup yang dimaksud dalam ketentuan ini antara lain pengendalian:

a. Pencemaran air, udara, dan laut, dan

b. Kerusakan ekosistem dan kerusakan akibat perubahan iklim

Peraturan lain yang terkait Taman Nasional diatur didalam Pasal 1 butir 14 Undang-Undang Nomor 5 Tahun 1990 tentang Konservasi Keanekara- 
gaman Hayati dan Ekosistemnya yang menyatakan bahwa Taman Nasional adalah kawasan pelestarian alam yang mempunyai ekosistem asli dikelola dengan sistem zonasi yang dimanfaatkan untuk tujuan penelitian, ilmu pengetahuan, pendidikan, menunjang budidaya, pariwisata, dan rekreasi.

Sedangkan didalam Pasal 1 butir 13 Undang-Undang Nomor 5 Tahun 1990 diatur tentang Kawasan Pelestarian Alam adalah kawasan dengan ciri khas tertentu, baik di darat maupun di perairan yang mempunyai fungsi perlindungan sistem penyangga kehidupan, pengawetan keanekaragaman jenis tumbuhan dan satwa, serta pemanfaatan secara lestari sumberdaya alam hayati dan ekosistemnya.

Pembagian Taman Nasional di Indonesia dibagi dalam dua kategori yaitu: Taman Nasional Darat dan Taman Nasional Laut. Total jumlah luasan Taman Nasional yang ada di indonesia hingga tahun 2004 tercatat telah mencapai 16.380.491.64 Ha dengan perincian untuk darat 12.336.950.34 Ha sedangkan laut 4.043.541.30 Ha.

Kriteria Penetapan Kawasan Taman Nasional (TN) adalah sebagai berikut:

1. Kawasan yang ditetapkan mempunyai luas yang cukup untuk menjamin kelangsungan proses ekologis secara alami;

2. Memiliki sumber daya alam yang khas dan unik baik berupa jenis tumbuhan maupun satwa dan ekosistemnya serta gejala alam yang masih utuh dan alami;

3. Memiliki satu atau beberapa ekosistem yang masih utuh;

4. Memiliki keadaan alam yang asli dan alami untuk dikembangkan sebagai pariwisata alam;

5. Merupakan kawasan yang dapat dibagi kedalam Zona Inti, Zona
Pemanfaatan, Zona Rimba dan Zona lain yang karena pertimbangan kepentingan rehabilitasi kawasan, ketergantungan penduduk sekitar kawasan, dan dalam rangka mendukung upaya pelestarian sumber daya alam hayati dan ekosistemnya, dapat ditetapkan sebagai zona tersendiri.

Asas manfaat mengandung makna bahwa pemanfaatan sumber daya hutan harus dapat memberikan manfaat yang sebesar-besarnya untuk kemakmuran rakyat banyak. ${ }^{7}$ Manfaat itu dapat dibedakan menjadi dua macam, yaitu:

1. Manfaat langsung adalah manfaat yang dapat dirasakan atau dinikmati secara langsung oleh masyarakat. Yaitu masyarakat dapat menggunakan dan memanfaatkan hasil hutan, antara lain kayu yang merupakan hasil utama hutan, serta berbagai hasil hutan ikutan, seperti rotan, getah, buah-buahan, madu dan lain-lain.

2. Manfaat tidak langsung adalah manfaat yang tak langsung dinikmati oleh masyarakat, tetapi yang dapat dirasakan adalah keberadaan hutan itu sendiri. ${ }^{8}$

Sedangkan manfaat yang dapat diberikan dari pengelolaan Taman Nasional jika dikaitkan dengan teori Bentham, hukum berperan sebagai penjaga keseimbangan dari berbagai kepentingan (balance of interest). Dalam konteks inilah sebenarnya Bentham menggangap hukum itu harus memberikan manfaat (utility) kepada manusia. Baik buruk atau adil tidaknya suatu hukum, bergantung kepada apakah hukum itu memberi-

7 Salim, Dasar-Dasar Hukum Kehutanan, Edisi Revisi, (Jakarta: Sinar Grafika, 2013), hlm.8.

8 Ibid., hlm. 46. 
kan kebahagiaan kepada manusia atau tidak. Sehingga pengelolaan Taman Nasional dapat memberikan manfaat antara lain:

1. Ekonomi

Dapat dikembangkan sebagai kawasan yang mempunyai nilai ekonomis, sebagai contoh potensi terumbu karang merupakan sumber yang memiliki produktivitas dan keanekaragaman yang tinggi sehingga membantu meningkatkan pendapatan bagi nelayan, penduduk pesisir bahkan devisa negara.

2. Ekologi

Dapat menjaga keseimbangan kehidupan baik biotik maupun abiotik di daratan maupun perairan.

3. Estetika

Memiliki keindahan sebagai obyek wisata alam yang dikembangkan sebagai usaha pariwisata alam/bahari.

4. Pendidikan dan Penelitian

Merupakan obyek dalam pengembangan ilmu pengetahuan, pendidikan dan penelitian.

5. Jaminan Masa Depan

Keanekaragaman sumber daya alam kawasan konservasi baik di darat maupun di perairan memiliki jaminan untuk dimanfaatkan secara batasan bagi kehidupan yang lebih baik untuk generasi kini dan yang akan datang.

Pengaturan mengenai Pengelolaan Taman Nasional yang ada didalam Undang-Undang Nomor 26 Tahun 2007 tentang Penataan Ruang menurut penulis tidak sesuai dengan pengaturan yang berlaku bagi Taman Nasional yaitu Peraturan Pemerintah Nomor 15 Tahun 2010 tentang Pengusahaan Pariwisata Alam di Suaka Margasatwa, Taman Nasional, Taman Hutan Raya dan Taman Wisata Alam dan Permenhut Nomor P.48/Menhut-II/2010 jo P.4/Menhut-II/2012 tentang Pengusahaan Pariwisata Alam di Suaka Margasatwa, Taman Nasional, Taman Hutan Raya dan Taman Wisata Alam dimana Kawasan Taman Nasional dikelola oleh Pemerintah. Taman Nasional dikelola dengan upaya pengawetan keanekaragaman jenis tumbuhan dan satwa beserta ekosistemnya.

Suatu kawasan Taman Nasional dikelola berdasarkan satu rencana pengelolaan yang disusun berdasarkan kajian aspek-aspek ekologi, teknis, ekonomis dan sosial budaya. Rencana pengelolaan Taman Nasional sekurangkurangnya memuat tujuan pengelolaan, dan garis besar kegiatan yang menunjang upaya perlindungan, pengawetan dan pemanfaatan kawasan.

Dalam hal ini Pemerintah Daerah tidak mempunyai kewenangan dalam pengelolaan Taman Nasional, sehingga aturan hukum yang ada dirasakan tidak sesuai dengan kewenangan kaitannya pelimpahan wewenang dari pusat kepada daerah, dikarenakan Pemerintah Daerah hanyalah bersifat koordinasi saja dan semua urusan pengelolaan Taman Nasional sepenuhnya dilakukan oleh Pemerintah Pusat yang dalam hal ini dilakukan oleh UPT Balai Taman Nasional.

Kawasan kehutanan penggunaan aturan yang berlaku tunduk pada bidang kehutanan karena adanya pembangian fungsi kawasan. Sedangkan penyelenggaraan tata ruang dikawasan kehutanan dengan sistem zonasi diatur di dalam Peraturan Pemerintah No. 15 Tahun 2010 tentang Penyelenggaraan Penataan Ruang dan Undang-Undang Nomor 26 Tahun 2007 tentang Penataan Ruang tidaklah absolutely diterapkan dikehutanan, karena apabila ditetapkan dikehutanan maka akan banyak yang terkena hukuman berdasarkan UUPR, hal ini bias terjadi perubahan fungsi kawasan hutan 
menjadi kawasan non hutan contoh tanah timbul di Jawa Barat. Perubahan fungsi kawasan non hutan menjadi kawasan hutan maka harus ditetapkan didalam review tata ruang yang dituangkan dalam Rencana Tata Ruang Wilayah Provinsi.

Pengelolaan Taman Nasional didasarkan atas sistem zonasi, yang dapat dibagi atas:

1. Zona inti;

2. Zona pemanfaatan;

3. Zona rimba;

4. Dan atau yang ditetapkan Menteri berdasarkan kebutuhan pelestarian sumberdaya alam hayati dan ekosistemnya.

Beberapa kegiatan yang dapat mengakibatkan perubahan fungsi kawasan Taman Nasional adalah:

1. Merusak kekhasan potensi sebagai pembentuk ekosistem;

2. Merusak keindahan dan gejala alam;

3. Mengurangi luas kawasan yang telah ditentukan;

4. Melakukan kegiatan usaha yang tidak sesuai dengan rencana pengelolaan dan atau rencana pengusahaan yang telah mendapat persetujuan dari pejabat yang berwenang.

Sesuatu kegiatan yang dapat dianggap sebagai tindakan permulaan melakukan kegiatan yang berakibat terhadap perubahan fungsi kawasan adalah:

1. Memotong, memindahkan, merusak atau menghilangkan tanda batas kawasan;

2. Membawa alat yang lazim digunakan untuk mengambil, menangkap, berburu, menebang, merusak, memusnahkan dan mengangkut sumberdaya alam ke dan dari dalam kawasan.
3. Taman Nasional dapat dimanfaatkan sesuai dengan sistem zonasinya :

a. Pemanfaatan Zona Inti: penelitian dan pengembangan yang menunjang pemanfaatan; ilmu pengetahuan; pendidikan; kegiatan penunjang budidaya.

b. Pemanfaatan Zona Pemanfaatan: pariwisata alam dan rekreasi; penelitian dan pengembangan yang menunjang pemanfaatan; pendidikan dan atau kegiatan penunjang budidaya.

c. Pemanfaatan Zona Rimba: penelitian dan pengembangan yang menunjang pemanfaatan; ilmu pengetahuan; pendidikan; kegiatan penunjang budidaya; wisata alam terbatas.

Pengaturan perlindungan dan pengelolaan lingkungan hidup terkait pemanfaatan ruang untuk Taman Nasional tidak sesuai pengaturannya di dalam Undang-Undang Nomor 26 Tahun 2007 tentang Penataan Ruang, serta peraturan lain yang terkait diantaranya yaitu Undang-Undang Nomor 32 Tahun 2009 tentang Perlindungan dan Pengelolaan Lingkungan Hidup, Undang-Undang Nomor 5 Tahun 1990 tentang Konservasi Sumber Daya Alam Hayati, Undang-Undang No. 32 Tahun 2004 jo Undang-Undang Nomor 23 Tahun 2014 tentang Pemerintahan Daerah dimana untuk pengelolaan Taman Nasional merupakan kawasan strategis termasuk wewenang Pemerintah Pusat dan Pemerintah Daerah baik Provinsi maupun Kabupaten/Kota. Dalam prakteknya, pengelolaan Taman Nasional berada pada Pemerintah Pusat dan Pemerintah Daerah hanya bersifat koordinasi dengan Unit Pelaksana Tugas (UPT) Balai Taman Nasional, yaitu memelihara kelestarian hutan dan yang berkaitan dengan 
perizinan dalam pengelolaan Taman Nasional antara lain:

1. Wisata

Ijin prasarana usaha pengusahaan sarana wisata alam

2. Jasa wisata alam seperti gaet, warung, photografi

Pemda dapat melakukan kerjasama apabila ada kegiatan di dalam Taman Nasional.

Jika dikaitkan dengan Teori Kewenangan dimana kekuasaan dari organ pemerintah melakukan kewenangannya, baik dalam lapangan hukum publik dan hukum privat dapat dibedakan menurut sumbernya, kepentingannya teritorial, ruang lingkupnya dan menurut urusan pemerintahan, maka dalam hal ini untuk urusan pengelolaan Taman Nasional termasuk dalam pembagian urusan Pemerintahan Daerah dibidang Kehutanan yang bersifat konkuren sehingga tidak sesuai dengan Undang-Undang Nomor 26 Tahun 2007 tentang Penataan Ruang yang menyebutkan bahwa pengelolaan kawasan strategis dalam hal ini Taman Nasional dilaksanakan oleh Pemerintah Pusat dan Pemerintah Daerah.

Hal ini dapat dilihat dari beberapa contoh Taman Nasional diantaranya dalam penelitian ini antara lain:

\section{Taman Nasional Bali Barat}

Penataan kawasan pengelolaan TNBB sesuai fungsi peruntukannya telah ditetapkan berdasarkan SK Dirjen Perlindungan dan Konservasi Alam No.186/Kpts/Dj-V/1999 tanggal 13 Desember 1999 tentang pembangian zonasi sebagai berikut:

a. Zona Inti; merupakan zona yang mutlak dilindungi, tidak diperbolehkan adanya perubahan apapun oleh aktivitas manusia kecuali yang berhubungan dengan kepentingan penelitian dan ilmu pengetahuan; meliputi daratan selauas $7.567,85$ hektar dan perairan laut seluas 455.37 hekta

b. Zona Rimba; merupakan zona penyangga dari zona inti, dapat dilakukan kegiatan seperti pada zona inti dan kegiatan wisata alam terbatas; meliputi daratan selauas $6.009,46$ hektar dan perairan laut seluas 243.96 hektar

c. Zona Pemanfaatan Intensif; dapat dilakukan kegiatan seperti pada kedua zona di atas, pembangunan sarana dan prasarana pariwisata alam dan rekreasi atau penggunaan lain yang menunjang fungsi konservasi sumber daya alam hayati dan ekosistemnya; meliputi daratan selauas 1.645,33 hektar dan perairan laut seluas 2.745.66 hektar

d. Zona Pemanfaatan Budaya; Zona ini dapat dikembangkan dan dimanfaatkan terbatas untuk kepentingan budaya atau relegi; seluas 245,26 hektar yang digunakan untuk kepentingan pembangunan sarana ibadat umat Hindu.

Khusus untuk zonasi pemanfaatan terbagi atas 3 pengelolaan yaitu:

a. PT. Trimbawan Swastama Sejati

b. PT. Shorea Barito Wisata

c. PT. Disthi Kumala Bahari

Pemanfaatan dibidang wisata alam dengan luas masing-masing $382 \mathrm{Ha}$ dengan jenis usaha penginapan dan restoran, yaitu Bali Tower yang dikelola oleh PT. Trimbawan Swastama Sejati dan PT. Shorea Barito Wisata. Sedangkan pemanfaatan dibidang atraksi wisata dikelola oleh PT. Disthi Kumala Bahari yaitu pembesaran kerang mutiara dimana para tamu asing dapat melihat budidaya kerang mutiara.

Pengelolaan hutan Bali Barat sebelum dikelola oleh Sub Balai Perlindungan dan Pelestarian Alam (PPA) Bali masih dalam pengelolaan Cabang 
Dinas Kehutanan Singaraja dan Jembrana sebagai unit dari Dinas Kehutanan Propinsi Bali, sedangkan unit pengelola terkecil wilayah yaitu RPH (Resort Pemangkuan Hutan) Penginuman, Sumberklampok dan Sumberkima. Kawasan Suaka Alam berupa cagar Alam atau Suaka Margasatwa dikelola oleh Sub Balai Perlindungan dan Pelestarian Alam (PPA) / SBKSDA Provinsi Bali sebagai Unit Pelaksana Teknis Dirjen PPA dengan unit pemangku terkecil di lapangan yaitu Kepala Resort sebagai pelaksana pengamanan dan perlindungan, yang dikepalai oleh Kepala Sub Seksi / Rayon Kawasan Suaka Margasatwa Bali Barat / Sub Seksi Wilayah PPA yang setara Eselon V.

Berdasarkan Surat Keputusan Menteri Kehutanan No. 096/KptsII/1984 tanggal 12 Mei 1984 tentang Organisasi dan Tata Kerja Taman Nasional Bali Barat, Suaka Alam Bali Barat dikelola sebagai UPT Taman Nasional Bali Barat.

Potensi-potensi yang dimiliki oleh Taman Nasional Bali Barat aebagai salah satu kawasan potensial alam di Bali sebagi berikut:
a. Potensi Fauna dan Flora Taman Nasional Bali Barat
b. Teluk Gilimanuk
c. Cekik dan Sekitarnya
d. Teluk Terima dan Semenanjung Prapat Agung
e. Pulau Menjangan
f. Banyuwedang dan Sekitarnya
g. Blimbingsari dan sekitarnya.

\section{Taman Nasional Bukit Baka Bukit Raya}

Taman Nasional Bukit Baka Bukit Raya (TNBBBR) dengan luas kawasan 181.090 hektar ditunjuk berdasarkan Surat Keputusan Menteri Kehutanan Nomor 281/ Kpts-II/ 1992 tanggal 26 Februari 1992 merupakan penggabu- ngan Cagar Alam Bukit Raya dan Cagar Alam Bukit Raya. Secara administratif TNBBBR terletak di Provinsi Kalimantan Barat (Kabupaten Sintang dan Kabupaten Melawi) dan Propinsi Kalimantan Tengah (Kabupaten Katingan). Kawasan ini memiliki peran vital terutama sebagai daerah tangkapan (catchment area) air bagi dua aliran sungai besar di Kalimantan, yaitu Sungai Melawi (Kalimantan Barat) dan Sungai Katingan (Kalimantan Tengah).

Keberadaan TNBBBR memberikan banyak peran serta manfaat bagi kehidupan dan kelangsungan hidup manusia,di antaranya yaitu :

a. Perlindungan dan pengawetan keanekaragaman hayati tumbuhan dan satwa beserta ekosistemnya.

b. Memelihara siklus air dan mencegah kondisi ekstrim (seperti banjir dan kekeringan). Menjamin ketersediaan air untuk kebutuhan rumah tangga dan pertanian bagi masyarakat yang berada di sekitar kawasan (wilayah Kabupaten Sintang, Kabupaten Melawi dan Kabupaten Katingan).

c. Melindungi tanah dari erosi dan longsor, sehingga dapat mencegah terganggunya produktivitas lahan pertanian dan perikanan.

d. Menyerap emisi CO2 di alam bebas sehingga dapat mengurangi timbulnya pemanasan global. Mekanisme alami yang terjadi dalam rantai ekosistem kawasan mampu menyerap karbon serta secara mikro dapat mendukung stabilitas iklim wilayah sekitar.

e. Sumberdaya alam dan ekosistemnya dapat mendukung berkembangnya kegiatan penelitian, pendidikan budidaya dan wisata alam.

Salah satu upaya mewujudkan pengelolaan TNBBBR yang efektif adalah melalui program Pengembangan Masyarakat Sadar Konservasi dengan 
bentuk kegiatan berupa: Bina Cinta Alam, Penyuluhan KSDA, Pemberdayaan Masyarakat serta Pemantapan Koordinasi dan Kerja Sama.

TNBBBR merupakan kawasan Taman Nasional yang meliputi wilayah Bukit Baka di Kalimantan Barat dan Bukit Raya di Kalimantan Tengah. Dulunya kedua kawasan ini adalah cagar alam. Namun sejak tahun 1992 berdasarkan SK Menteri Kehutanan No. 281/Kpts-II/1992 menjadi Taman Nasional. Di Kalimantan Barat, kawasan TNBBBR masuk wilayah Kabupaten Sintang dan Melawi, sedangkan di Kalimantan Tengah, kawasan ini berada dalam wilayah administratif Kabupaten Katingan. Terkait pengelolaan kolaboratif TNBBBR berdasarkan peraturan Menteri Kehutanan Nomor P.19/ Menhut/2004, definisi pengelolaan kolaboratif adalah pelaksanaan suatu kegiatan atau penanganan suatu masalah dalam rangka membantu meningkatkan efektivitas pengelolaan Kawasan Suaka Alam dan Kawasan Pelestarian Alam secara bersama dan sinergis oleh para pihak atas dasar kesepahaman dan kesepakatan bersama sesuai dengan peraturan perundang-undangan yang berlaku.

Sementara Kepala Bappeda Kabupaten Sintang, Drs. Sontong, MSi, menuturkan bahwa Pemerintah dan masyarakat Kabupaten Katingan sangat mendukung pengelolaan kawasan TNBBBR karena peran penting TNBBBR untuk kawasan dibawahnya. Oleh karena itu, perlu adanya koordinasi dan kolaborasi dalam upaya pengamanan bersama yang dituangkan dalam bentuk renstra pengelolaan TNBBBR, yang juga terkait pengembangan masyarakat di sekitar TNBBBR.

Beberapa hal yang menjadi kesepakatan untuk ditindaklanjuti yakni:

a. Pemerintah Kabupaten Katingan mendukung sepenuhnya kegiatan dan keberadaan Taman Nasional Bukit Baka Bukit Raya

b. Pemerintah Kabupaten Katingan mengharapkan agar wilayah Taman Nasional Bukit Baka Bukit Raya yang termasuk wilayah administratif Kabupaten Katingan untuk dijadikan Balai Taman Nasional tersendiri terpisah dari Balai Taman Nasional Bukit Baka Bukit Raya.

c. Adanya RENSTRA untuk pengembangan masyarakat sekitar Taman Nasional Bukit Baka Bukit Raya

d. Seluruh pengelolaaan SDA menerapkan pola kemitraan dan mensejahterakan masyarakat di sekitar serta ramah lingkungan

e. Adanya program bersama yang dibahas secara intensif terhadap kegiatan yang akan dilaksanakan pada Taman Nasional Bukit Baka Bukit Raya

f. Melakukan perlindungan kawasan Taman Nasional Bukit Baka Bukit Raya dengan melibatkan stakeholder terkait.

g. Melakukan tindak lanjut secara kontinyu untuk sinkronisasi, sosialisasi dan pembagian peran dalam pembinaan serta pengembangan masyarakat di sektiar kawasan TNBBBR secara terpadu antar pihak baik pemerintah Kabupaten Katingan, Balai TNBBBR, masyarakat Desa Penyangga, LSM, akademisi, pers seperti kegiatan peningkatan ekonomi, pemberdayaan masyarakat, penguatan kelembagaan adat dan penataan hukum adat dalam menjaga kelestarian hutan.

h. Mempercepat penyelesaian zonasi TNBBBR secara definitif

i. Membentuk forum kolaborasi dan membangun mekanisme komunikasi antar para pihak untuk men- 
jembatani informasi-informasi terkait pengelolaan TNBBBR

j. Inventarisasi, identifikasi dan implementasi kegiatan-kegiatan pembangunan masyarakat desa penyangga TNBBBR dalam rangka mengelola TNBBBR secara bersama-sama

k. Penambahan personil POLHUT untuk pengamanan serta Penyuluh Kehutanan.

Kawasan Taman Nasional adalah kawasan pelestarian alam yang mempunyai ekosistem asli, dikelola dengan sistem zonasi yang dimanfaatkan untuk keperluan penelitian, ilmu pengetahuan, pendidikan, menunjang budidaya, pariwisata dan rekreasi (UU No 41/1999). Kawasan tersebut memiliki fungsi utama untuk perlindungan sistem penyangga kehidupan, pengawetan keanekaragaman jenis tumbuhan dan satwa, serta pemanfaatan secara lestari sumberdaya alam hayati dan ekosistemnya (UU No 5/1990). Namun pengelolaan Taman Nasional sampai saat ini masih menitikberatkan pada perlindungan dan pengawetan, sedangkan dari segi pemanfaatan masih belum berjalan sebagaimana mestinya. Hal ini disebabkan oleh adanya suatu pandangan bahwa konservasi hanya menyangkut perlindungan dan pengawetan saja, sehingga berbagai kegiatan masyarakat yang dianggap akan merusak atau merubah bentang alam dari hutan tidak boleh dilakukan, sehingga seringkali memicu konflik.

\section{Kendala-Kendala dalam Pengelo- laan Taman Nasional}

Pengelola kawasan-kawasan konservasi menghadapi berbagai persoalan yang kompleks dan beragam. Persoalan dapat dikelompokkan ke dalam persoalan internal dan eksternal.

1. Persoalan Internal
Yang dimaksud persoalan internal adalah menyangkut organisasi dan kelembagaan Balai.

a. Sistem Perencanaan

Rencana Pengelolaan (RP). Pengelolaan suatu kawasan konservasi didasarkan pada suatu RP yang berjangka 20-25 tahun, yang diterjemahkan ke dalam Rencana Karya Lima tahun (RKL), dan Rencana Karya Tahunan (RKT). Persoalan yang pada umumnya muncul adalah sebagian besar kawasan konservasi belum memiliki rencana pengelolaan tersebut.

b. Tata Batas dan Pemangkuan Kawasan

Tata batas sebagai salah satu prakondisi pengelolaan kawasan konservasi menjadi salah satu kendala. Kondisi perkembangan tata batas kawasan konservasi adalah sebagai berikut:

1) Belum tata batas $(24,8 \%)$,

2) Sudah tata batas-belum temu gelang $(18,2 \%)$,

3) Sudah tata batas temu gelang $(17,6 \%)$

4) Sudah temu gelang dengan BATB sudah selesai $(16,5 \%)$,

5) Sudah penetapan $(24,6 \%)$.

Organisasi belum mampu membangun sistem pengelolaan yang berbasis pada pola pemangkuan kawasan. Resortresort sebagai unit terkecil manajemen kawasan di tingkat lapangan belum dibangun. Di beberapa Taman Nasional di Pulau Jawa telah dimulai sistem ini. Kita dapat mencontoh konsep Kesatuan Pengelolaan Hutan (KPH) Perum Perhutani, di mana kawasan hutannya dibagi habis sampai ke dalam RPH (Resort Polisi Hutan). Mereka bekerja di tingkat lapangan, dengan peta 
kerja skala 1:10.000. Dengan demikian, maka semua informasi tentang kawasan dapat dipetakan dan dijadikan dasar untuk melakukan tindakan perencanaan dan manajemen kawasan secara detail.

c. Leadership dan Manajemen

Arahan kebijakan ini telah dituangkan dalam Permenhut P.19/2004 tentang "Kolaborasi Pengelolaan KPA/KSA. Diperlukan waktu 24 tahun (apabila dihitung dari deklarasi 5 Taman Nasional pertama pada tahun 1980), untuk mendorong polapola baru dalam pengelolaan kawasan konservasi, yang lebih inklusif dengan melibatkan para pihak.

2. Persoalan Eksternal

a. Perebutan Ruang dan Aset Ekonomi

b. Posisi Masyarakat Adat

c. Sinergitas Kemitraan

Dalam pengelolaan Taman Nasional bersifat otonom yang pada intinya walaupun wilayahnya secara administratif ada disuatu Kabupaten/Kota, pintu masuk Pemda setempat ke Taman Nasional adalah hanya sebatas retribusi atas jasa wisata alam yang dimiliki oleh kawasan Taman Nasional tersebut dan tidak memiliki kewenangan dalam mengelola Taman Nasional.

Pada hakekatnya Taman Nasional hanya mengelola dalam kawasan, selama ini pengawasan atas seluruh kawasan belum optimal, mengingat luasnya kawasan yang harus di awasi dan dilindungi. Maka jika dilihat dari tujuan diadakannya peraturan perundang-undangan yang ada seharusnya Negara sebagai suatu organisasi kekuasaan yang dibentuk guna mengatur dan mengurus serta menyelesaikan segala kepentingan-kepentingan dari seluruh rakyat Indonesia. Untuk meningkatkan manfaat wilayah atau kawasan yang maksimal maka diperlukan perhatian yang teliti terhadap perlindungan lingkungan, efisiensi, sinergi dan keserasian pada potensi ekonomi dilingkungan tersebut, sehingga keterpaduan dalam perencanaan pembangunan mencapai hasil yang maksimal dalam peningkatan kesejahteraan.

Dikaitkan dengan Teori Negara kesejahteraan dimana tugas dan peran Negara sangat luas yaitu melaksanakan penyelenggaraan kepentingan umum dan secara aktif berusaha untuk mensejahterakan rakyat, dimana dalam pengelolaan Taman Nasional peranan UPT Balai Taman Nasional dikelola dengan sistem zonasi dan merupakan perpanjangan tangan dari pemerintah pusat, sehingga untuk mewujudkan suatu kesejahteraan $\mathrm{Ne}$ gara hal itu belum terwujud dikarenakan semua hasil dari pendapatan/ kontribusi yang ada didalam Taman Nasional seluruhnya disetorkan kepada pusat dalam hal ini adalah Kementerian Kehutanan dan yang terkena imbasnya adalah Taman Nasional terkait dengan dana untuk pengelolaan Taman Nasional, dimana tidak ada bantuan dana dari Pemda setempat dikarenakan Pemda setempat hanya bersifat koordinasi apabila ada kegiatan di dalam Taman Nasional. Hal ini terlihat jelas bahwa kurang efektifnya kesejahteraan bagi UPT Balai Taman Nasional berdampak terhadap kesejahteraan masyarakat setempat di dalam kawasan Taman Nasional.

\section{Taman Nasional Bali Barat}

Berdasarkan dari pengamatan penulis bahwa kendala yang ada di Taman Nasional Bali Barat dimana Pemerintah Daerah tidak ada bantuan dana dan hanya bersifat koordinasi sehingga Pemerintah Daerah tidak dapat langsung terlibat dalam penge- 
lolaan Taman Nasional dikarenakan pengelolaan Taman Nasional langsung dari Pemerintah Pusat. Selain itu juga untuk sarana prasana harus menunggu dana dari Pemerintah Pusat dan tidak dapat dipenuhi secara cepat. Khusus Taman Nasional Bali Barat lebih fokus pada jalak Bali maka dana lebih besar sedangkan pemasukan lebih banyak dari sektor wisata.

Selain hal tersebut diatas maka di dalam Taman Nasional ekosistem yang ada harus asli dimana bentang alam tidak boleh diubah sama sekali walaupun dibuat jalur trakking harus sealami mungkin.

\section{Taman Nasional Bukit Baka Bukit Raya}

Salah satu Taman Nasional penting di kawasan Heart of Borneo yaitu Taman Nasional Bukit Baka Bukit Raya, yang berada di kawasan Kalimantan Barat dan Kalimantan Tengah, telah menyelesaikan beberapa tahapan penting dalam penyusunan dokumen perencanaan kerja jangka panjang. Salah satu permasalahan yang menjadi tugas penting pengelolaan kawasan Taman Nasional ini ke depan adalah tata batas kawasan. Saat ini situasinya adalah belum temu gelang, beberapa titik di atas peta maupun di lapangan masih belum sinkron, terutama dengan areal hutan produksi dan tanah adat masyarakat, baik di sisi Kalimantan Barat maupun Kalimantan Tengah.

Kawasan Taman Nasional ini berbatasan langsung dengan beberapa areal konsesi HPH dan beberapa perkampungan yang masyarakatnya masih melakukan aktivitas perladangan pola berpindah, pengumpulan hasil hutan dan berburu.

Beberapa bukit merupakan hulu sungai yang berupa anak sungai, ada pula yang berupa air terjun. Keragaman lokasi tersebut mengharuskan pihak pengelola untuk membagi habis kawasan ke dalam tata ruang atau zona-zona yang sesuai dengan peruntukannya.

Pembiayaan pengelolaan kawasan dan kegiatan konservasi Taman Nasional Bukit Baka Bukit Raya tidak mungkin dicukupi hanya dari keuangan negara. Pengelola Taman Nasional Bukit Baka Bukit Raya perlu menyusun strategi pendanaan berkelanjutan. Beberapa kemungkinan pendanaan yang terindentifikasi adalah:

1) Pendanaan dari pemerintah provinsi dan kabupaten, melalui mekanisme pengumpulan dan pembagian hasil pajak dan non-pajak serta melalui mekanisme pendanaan yang dikembangkan oleh daerah.

2) Dana mitra konservasi bersama LSM lingkungan yang bekerja di kawasan Taman Nasional Bukit Baka Bukit Raya.

3) Pembayaran Jasa Lingkungan berdasarkan potensi kekayaan alam misalnya daya serap karbon, keindahan alam dan lansekap, perlindungan DAS dan tata air, serta kekayaan keragaman hayati. Daya serap karbon dapat diwujudkan dengan mekanisme pembayaran rehabilitasi dan restorasi ekosistem di areal yang perlu direhabilitasi seperti bekas areal $\mathrm{HPH}$, lahan bekas kebakaran dan kerusakan hutan lainnya. Skema perdagangan karbon juga bisa direalisasikan melalui pengembangan program pengelolaan hutan berbasis masyarakat.

4) Produk-produk yang dihasilkan dari budidaya masyarakat lokal juga dapat dikemas dan diberi label konservasi untuk diperdagangkan di pasar hijau.

Dari berbagai kemungkinan di atas, pengelola Taman Nasional Bukit Baka Bukit Raya perlu membangun peren- 
canaan program bersama dengan pihak lain di luar Taman Nasional, pihak lain tersebut berupa program-program di pemerintah daerah (Pemda) melalui Musyawarah Perencanaan Pembangunan (Musrenbang) baik di tingkat desa maupun di kabupaten, ataupun penyusunan program bersama LSM maupun pihak swasta yang tertarik dan berminat dengan isu ataupun obyek tertentu. Penyusunan program ini akan berjalan dengan sharing pendanaan atau sumber daya masing-masing pihak.

\section{Pengaturan yang Ideal Mengenai Pengelolaan Taman Nasional Agar PEMDA Dapat Berperan Sesuai Dengan Amanat UUPR}

Penataan ruang dipandang sebagai upaya untuk memanfaatkan sumber daya alam sebesar-besarnya bagi kesejahteraan rakyat. Namun demikian, penataan ruang juga harus dapat menjamin kelestarian sumber daya alam agar dapat berfungsi secara terusmenerus. Karena sifat penataan ruang yang irreversible maka perencanaan penataan ruang harus mempertimbangkan kebutuhan, kemampuan dan kapasitas dalam melaksanakan dan mengendalikan pelaksanaan tata ruang yang disusun.

Dalam rangka penyusunan dan pelaksanaan program pembangunan ke depan yang efektif dan efisien adalah dengan memperhatikan karakteristik kawasan, antara lain kondisi infrastruktur dalam hal ini yang mendukung pertumbuhan maupun pemerataan aktivitas ekonomi. Untuk selanjutnya diperlukan juga strategi pembangunan yang tepat, guna mempercepat pembangunan pada daerah yang sedang berkembang dalam mengejar ketinggalan. Salah satu strategi tersebut adalah dengan menggunakan pendekatan kawasan melalui penataan ruang secara benar.

Penataan ruang adalah suatu konsep pemikiran atau gagasan yang mencakup penataan semua kegiatan beserta karakteristiknya berkaitan dengan ruang atau lokasi dalam suatu wilayah kawasan. Untuk meningkatkan manfaat wilayah atau kawasan yang maksimal diperlukan perhatian yang teliti terhadap perlindungan lingkungan, efisiensi, sinergi dan keserasian pada potensi ekonomi di lingkungan tersebut. Ini dapat diartikan bahwa pentingnya keterpaduan dalam perencanaan pembangunan adalah untuk mencapai peningkatan kesejahteraan yang maksimal.

Kawasan konservasi sendiri merupakan kawasan hutan yang ditetapkan untuk perlindungan ekosistem dan spesies (flora, fauna, dan biodiversity). Menurut fungsinya, kawasan konservasi dibedakan menjadi dua yakni kawasan perlindungan alam dan suaka alam. Untuk kawasan perlindungan alam meliputi Taman Nasional, Taman Hutan Raya, serta Taman Wisata. Sedangkan yang termasuk dalam suaka alam adalah suaka margasatwa dan cagar alam. Namun saat ini, sebagian besar kawasan konservasi mengalami degradasi baik fungsi maupun kuantitasnya. Selain karena faktor alam (misalnya erupsi gunung berapi, gempa bumi ataupun tsunami) juga disebabkan oleh perubahan fungsi dan ulah manusia. Masyarakat masih memiliki tingkat ketergantungan yang tinggi terhadap sumber daya alam yang ada di kawasan konservasi. Sebagian masyarakat memenuhi berbagai kebutuhan hidup seperti pangan, sandang, dan bahan bangunan seringkali masih mengambil dari dalam kawasan konservasi. Selain itu, adanya konflik 
nyata dari berbagai sektor seperti kehutanan dan perkebunan menjadi salah satu faktor penyebab degradasi. Diperlukan adanya kebijakan Pemerintah untuk memaduserasikan sektor kehutanan, pertambangan, dan perkebunan. RTRW merupakan alat yang mengakomodir kepentingan semua sektor.

Tata ruang dapat menjadi salah satu upaya konservasi sumber daya alam, karena tata ruang berusaha mengendalikan pemanfaatan sumber daya alam secara berkesinambungan. Sebelum dikenal penataan ruang, sebenarnya sudah ada tata ruang yang berjalan sesuai dengan adat dan kebiasaan suatu masyarakat, dimana sebagai pengaturnya dan pengendalinya berupa tradisi yang memandang bahwa alam adalah sebagai tempat hidup, sumber hidup, dan sarana bergantung. Karena keberadaannya yang sangat penting maka secara tidak langsung tata ruang terbentuk dengan sendirinya sebagai upaya konservasi sumber daya alam melalui bentukbentuk kearifan lokal. Namun, seiring dengan meningkatnya kebutuhan masyarakat, meningkatnya jumlah penduduk dan terbatasnya lahan, kearifan-kearifan lokal tersebut semakin berkurang dan perlu diatur melalui mekanisme penataan ruang.

Menurut Teori Kemanfaatan Hukum menurut Jeremy Bentham menganggap hukum itu harus memberikan manfaat (utility) kepada manusia, baik buruk atau tidak adilnya suatu hukum bergantung kepada apakah hukum itu memberikan kebahagiaan kepada manusia atau tidak. Jika dikaitkan dengan Pengelolaan Taman Nasional agar hukum itu bermanfaat maka seharusnya dilakukan pelimpahan kewenangan secara medebewind kepada Pemerintah Daerah yaitu dalam mengelola Taman Nasional dapat lang- sung bertanggungjawab kepada Pemerintah Pusat sehingga Pemerintah Daerah dapat melakukan pengelolaan Taman Nasional dengan penguatan Dinas Lingkungan Hidup dalam kerjasama dengan Program Keanekaragaman Hayati Indonesia (Kehati) Pemanfaatan Taman Nasional dipadukan antara Rencana Pengelolaan Jangka Menengah Taman Nasional (RPJM TN) dan Rencana Pengelolaan Jangka Menengah Daerah (RPJMD) Pemda mengadakan musrenbang maka pihak Taman Nasional juga wajib diundang agar ada korelasi kegiatan pembangunan dan Taman Nasional dan jika bisa ada kegiatan kolaboratif antar keduanya, jadi tidak ada dikotomi kaku sesama Stakeholder dibidang lingkungan.

Selain itu juga program dan kegiatan Pemda selalu dibahas dengan DPRD setempat supaya pemahaman legislatif didaerah tentang lingkungan dan kehutanan sangat minim dan selalu dikaitkan dengan Pendapatan Anggaran Daerah. Dalam penyusunan RPJMD Pemda juga haruslah mempelajari apa itu Taman Nasional karena secara administratif ada diwilayah Pemda, apalagi jika melihat RTRW setiap Pemda ada kawasan lindung. Intinya Pemerintah Daerah harus perhatian bahwa Taman Nasional itu juga berada dalam tanggung jawabnya secara administratif, sosial dan ekonomi sehingga memungkinkan ada kegiatan integratif antara Pemerintah Daerah dengan Taman Nasional.

\section{PENUTUP}

Pengaturan perlindungan dan pengelolaan lingkungan hidup terkait pemanfaatan ruang untuk Taman Nasional tidak sesuai pengaturannya di dalam Undang-Undang Nomor 26 
Tahun 2007 tentang Penataan Ruang, serta peraturan lain yang terkait diantaranya yaitu Undang-Undang Nomor 32 Tahun 2009 tentang Perlindungan dan Pengelolaan Lingkungan Hidup, Undang-Undang Nomor 5 Tahun 1990 tentang Konservasi Sumber Daya Alam Hayati, Undang-Undang No. 32 Tahun 2004 jo Undang-Undang Nomor 23 Tahun 2014 tentang Pemerintahan Daerah, dinyatakan bahwa untuk pengelolaan Taman Nasional merupakan kawasan strategis termasuk wewenang Pemerintah Pusat dan Pemerintah Daerah baik Provinsi maupun Kabupaten/Kota. Pengaturan yang berlaku bagi Taman Nasional yaitu Peraturan Pemerintah Nomor 15 Tahun 2010 tentang Pengusahaan Pariwisata Alam di Suaka Margasatwa, Taman Nasional, Taman Hutan Raya dan Taman Wisata Alam dan Permenhut Nomor P.48/Menhut-II/2010 jo P.4/Menhut-II/2012 tentang Pengusahaan Pariwisata Alam di Suaka Margasatwa, Taman Nasional, Taman Hutan Raya dan Taman Wisata Alam dimana Kawasan Taman Nasional dikelola oleh Pemerintah.

Pada hakekatnya Taman Nasional hanya mengelola dalam kawasan, selama ini pengawasan atas seluruh kawasan belum optimal, mengingat luasnya kawasan yang harus di awasi dan dilindungi. Pengelolaan kawasan konservasi Taman Nasional menghadapi berbagai persoalan yang kompleks dan beragam. Persoalan dapat dikelompokkan ke dalam persoalan internal dan eksternal.

a. Persoalan Internal. Persoalan internal adalah menyangkut organisasi dan kelembagaan Balai Taman Nasional:

1) Sistem perencanaan

2) Tata Batas dan pemangku kawasan

3) Leadership dan Manajemen b. Persoalan Eksternal:

1) Perebutan ruang dan asset ekonomi

2) Posisi Masyarakat adat

3) Sinergitas kemitraan

Pengaturan mengenai pengelolaan Taman Nasional belum ideal karena peraturan yang ada menyebutkan bahwa pengelolaan Taman Nasional adalah wewenang Pemerintah Pusat dan Pemerintah Daerah sedangkan Taman Nasional dikelola langsung oleh Pemerintah Pusat dalam hal ini Unit Pelaksana Teknis Balai Taman Nasional, sehingga peranan Pemerintah Daerah belum berperan karena hanya bersifat koordinasi dalam mengelola Taman Nasional, dimana pengelolaan Taman Nasional sepenuhnya merupakan kewenangan dari Pemerintah Daerah.

\section{DAFTAR PUSTAKA}

\section{BUKU}

A.D. Belinfante dan Burhanoeddin Soetan Batuah, Pokok-Pokok Hukum Tata Usaha Negara, Bandung: Binacipta, 1983.

Achmad Ali, Menguak Tabir Hukum, Kajian Fllosofis Dan Sosiologis, Jakarta: Toko Gunung Agung, 2002.

Amich Alhumami, Negara Kesejahteraan, www.freelist.org. tanggal 26 Juni 2007.

Amiruddin, Zainal Asikin, Pengantar Metode Penelitian Hukum, Jakarta: Raja Grafindo Persada

Ateng Syafrudin, Menuju Penyelenggaraan Pemerintahan Negara yang Bersih dan 
Bertanggung Jawab, Jurnal Pro Justisia Edisi IV, Bandung: Universitas Parahyangan, 2000.

B. Milles dan A. Michael Haberman, Analisis Data Kualitatif, Terj. Tjetjep Rohendi Rohidi Jakarta, 1992.

Bachtiar Effendie, Kumpulan Tulisan tentang Hukum Tanah, Bandung: Alumni, 1993.

Bachtiar Effendie, Pendaftaran Tanah Di Indonesia Dan PeraturanPeraturan Pelaksanaannya, Bandung: Alumni, 1983.

Boedi Harsono. Hukum Agraria Indonesia. Sejarah Pembentukan Undang-undang Pokok Agraria, Isi dan Pelaksanaannya Jakarta: Universitas Trisakti, 2013.

CFG. Sunaryati Hartono, Hukum Ekonomi Pembangunan Indonesia, Bandung: Bina Cipta, tanpa tahun.

H. Amrah Muslimin, Beberapa asas dan pengertian pokok tentang adininistrasi dan hukum administrasi, Bandung: Alumni, 1985.

Hasni, Hukum Penataan Ruang Dan Penatagunaan Tanah Dalam Konteks UUPA-UUPR-UUPPLH, Edisi Ketiga, Jakarta: PT. RajaGrafindo Persada, 2013.

Henry Campbell Black, Black's Law Dictionary, Amerika Serikat: West Publishing Co., 1978.

Jeremy Bentham, Pengantar Bagi Azasazas Moral dan PerundangUndangan, (Introduction To The Principles of Morals and Legislation, London, 1780, Revisi Edisi.
Koesnadi Hardjasoemantri, Hukum Tata Lingkungan, Edisi Kedelapan Cetakan Kedelapan Belas, Yogyakarta: Gadjah Mada University Press, 2005.

Marbun SF dan Moh. Mahfud MD, Pokok-Pokok Hukum Administrasi Negara, Yogyakarta: Liberty, 1987.

Moll. Koesnardi clan Bintan Saragih, Ilmu Negara, Jakarta: Gaya Media Pertama, 1988.

Mubyarto, Sistem dan Moral Ekonoini Indonesia, Jakarta: Peneibit LP3ES, 1994.

Muhamad Erwin, Filsafat Hukum Refleksi Kritis Terhadap Hukum, Prolog Prof. Dr. Saldi Isra, SH Jakarta: Rajawali Press, 1994.

Muhammad Yamin, Naskah Persiapan UUD 1945, Jilid /, Percetakan Siguntang. Jakarta.

Nasution, Metode Penelitian Naturalistik Kualitatif, Bandung, 1996.

P. Sondang Siagian, Adininistrasi Pembangunan, Jalarta: Haji Masagung, 1988.

Philipus M. Hadjon dan Kawan-kawan, Pengantar Hukum Administrasi Indonesia, Yogyakarta: Gajahmada University Press, 1994.

Philipus M. Hadjon, "Tentang Wewenang Pemerintahan (Bestuurbevoegdheid)", Pro Justitia Tahun XVI Nomor 1 Januari 1998. 
Prajudi Atmosudirdjo, Hukum Administrasi Negara, Jakarta: Ghalia Indonesia, 1984.

Pustaka Setia, UUD 1945 Setelah Amandemen Keempat Tahun 2002, GBHN (Tap MPR No. IV/MPR/J999) 1999-2004, Bandung, 2002.

Ridwan HR, Hukum Administrasi Negara, Jakarta: Raja Grafindo Persada, 2008.

Ridwan, HR, Hukum Administrasi Negara, Yogyakarta, UII-Press, 2003.

Ronny Hanitijo Soernitro, MasalahMasalah Sosiologi Hukum, Bandung: Sinar Bara, 1984.

Roscoe Pound, An Introduction to the Philosophy of Law, Yale University Press, New Haven, 1959.

Roscoe Pound, Pengantar Filsafat Hukum, (terjemahan), Jakarta: Bhatara Karya Aksara, 1982.

Salim, S.H., Dasar-Dasar Hukum Kehutanan, Edisi Revisi, Jakarta: Sinar Grafika, 2013.

Samidjo, Ilmu Negara, Annico, Bandung, 1986.

Soerjono Soekanto, Kesadaran Hukum dan Kepatuhan Hukum, Jakarta: Rajawali Pers, 1984.

Soerjono Soekanto, Pengantar Penelitian Hukum, Jakarta: UI Press, 1984.

Soerjono Soekanto, Sosiologi Suatu Pengantar, Jakarta: RajaGrafindo Persada, 2005.
Sudargo Gautama, Pengertian Tentang Negara Hukum, Bandung: Alumni, 1983.

Sumartono, Hukum Ekonomi, Universitas Indonesia, Jakarta, 1986.

Syachran Basa, Tiga Tulisan Tentang Hukum, Bandung: Armico, 1986.

Syacran Basah, Sistem Perizinan Sebagai Instrument Pengendali Lingkungan, Dalam Butir-butir Gagasan Tentang Penyelenggaraan Hukum dan Pemerintahan yang layak, Sebuah Tandamata 70 Tahun Ateng Syafrudin, Bandung: Citra Aditya Bhakti, 1996.

TIM, Hasil Penelitian tentang Penyusunan Materi Teknis Pengaturan Pelaksanaan Hak Warga Negara Dalam Pemanfaatan Ruang, Kerjasama Direktorat Tata Kota dan Tata Bangunan Direktorat Jenderal Ciptakarya, Departemen Pekerjaan Umum dan Fakultas Hukum Universitas Padjajaran Bandung, 7 September 1992.

W. Tri Widodo Utomo, Hukum Pertanahan. Dalam Perspektif Otonomi Daerah, Yogyakarta: Navila, 2002.

Yudha Bhakti Adhiwisastra, Imunitas Kedaulatan Negara di Forum Pengadilan Asing, Bandung: Alumni, 2003. 


\section{PERATURAN} UNDANGAN

Undang-Undang Dasar 1945.

Undang-Undang Nomor 5 Tahun 1960 tentang Peraturan Dasar PokokPokok Agraria.

Undang-Undang Nomor 5 Tahun 1990 tentang Konservasi Sumber Daya Alam Hayati.

Undang-Undang Nomor 41 Tahun 1999 tentang Kehuatanan.

Undang-Undang Nomor 26 Tahun 2007 tentang Penataan Ruang.

Undang-undang Nomor 32 Tahun 2009 tentang Perlindungan dan Pengelolaan Lingkungan Hidup.

Undang-Undang Nomor 23 Tahun 2014 tentang Pemerintahan Daerah.

Peraturan Pemerintah Nomor 13 Tahun 1994 tentang Perburuan Satwa Buru.

Peraturan Pemerintah Nomor 68 Tahun 1998 tentang Kawasan Suaka Alam dan Kawasan Pelestarian Alam.

Peraturan Pemerintah No. 45 Tahun 2004 tentang Perlindungan Hutan,

Peraturan Pemerintah Nomor 38 Tahun 2007 tentang Pembagian Urusan Pemerintahan.

Peraturan Pemerintah Republik Indonesia Nomor 16 Tahun 2004 tentang Penatagunaan Tanah.

Peraturan Pemerintah Nomor 26 Tahun 2008 tentang Rencana Tata Ruang Wilayah Nasional.
Peraturan Menteri Kehutanan Nomor P.19/Menhut-II/2004 tentang Kolaborasi Pengelolaan Kawasan Suaka Alam Dan Kawasan Pelestarian Alam.

Peraturan Menteri Kehutanan Nomor P. 56/Menhut-II/2006 tentang Pedoman Zonasi Taman Nasional Menteri Kehutanan.

Peraturan Menteri Lingkungan Hidup dan Kehutanan Nomor: P.18/MenLHK-II/2015 tentang Organisasi dan Tata Kerja Kementerian Lingkungan Hidup dan Kehutanan.

Peraturan Menteri Lingkungan Hidup dan Kehutanan Nomor: P. 7/Menlhk/Setjen/OTL.0/1/2016 tentang Organisasi dan Tata Kerja Unit Pelaksana Teknis Taman Nasional

Peraturan Daerah Nomor 11 Tahun 2011 tentang Rencana Tata Ruang Wilayah Kabupaten Jembrana Tahun 2012-2032.

Peraturan Daerah Kabupaten Sintang Nomor 20 Tahun 2015 tentang Rencana Tata Ruang Wilayah Kabupaten Sintang Tahun 20162036.

Keputusan Menteri Kehutanan Nomor 390/Kps-II/2004 tentang Tata Cara Kerjasama di Kawasan Konservasi.

Keputusan Presiden Nomor 32 Tahun 1990 tentang Pengelolaan Kawasan Lindung. 


\section{ON-LINE DARI INTERNET}

Diah Restuning Maharani, Teori Kewenangan,

http://restuningmaharani.blogspot. $\mathrm{com} / 2009 / 10 /$ teori-

kewenangan.html, diakses pada tanggal 20 Oktober 2012.

Enid Campbell, et.al., Legal Research, Materials and Methods, (Sydney: The Law Book Company Limited, 1998), hal. 1 